\title{
MODEL PEMBANGKIT LISTRIK TENAGA OMBAK
}

\author{
Andi Faharuddin ${ }^{1}$, Andika Saputra $^{2}$, Satriani ${ }^{3}$ \\ ${ }^{1,2,3}$ Program Studi Teknik Elektro Fakultas Teknik Unismuh Makassar \\ e-mail: afahar@gmail. $\mathrm{com}^{1}$, andikabrekele@yahoo. $\mathrm{com}^{2}$, anhycimpa@yahoo.co.id ${ }^{3}$
}

\begin{abstract}
This research purposes create a prototype power plant and how the results of the prototype wave power plant. The study was conducted implemented during the month of November 2015 is located in the village of Bontosunggu, district Tamalatea, Jeneponto of South Sulawesi. prototype wave power plant by using an input high water with poles tapered rear and front pole 0:40 am 0:20 am to $0: 20 \mathrm{~m}$ wide rear and width of the front of the 0:30 am. This prototype also has an a reservoir (reservoir) with a height of $0: 45 \mathrm{~m}$, width of $0.28 \mathrm{~m}$ square. And pipe $1 / 2$ inches long with $1.8 \mathrm{~m}$ as the water supply to the water turbine. Used water turbine has an 10 propeller to rotate a generator (dynamo DC) 6 Volt 2.4 Watt. High variation waves used are 0:32 am, 12:40 am and 0:42 am. Research results showed that the water is able to rise to the reservoir at 11:00 am until 14:00 with a varied high waves. And the power that can be generated by a dynamo maximum and minimum 1.1667 0.7702 Volt Volt. Prototype wave power plant this models has three important buildings and capable of generating electrical energy with an average voltage of 1 volt.
\end{abstract}

Intisari-Krisis energi diperkirakan akan melanda dunia sekarang dan yang akan datang. Hal ini dikarenakan semakin meningkatnya permintaan energi. Tujuan penelitian ini membuat prototipe pembangkit listrik dan bagaimana hasil dari penelitian pembangkit listrik tenaga ombak. Penelitian dilaksanakan selama bulan November 2015 berlokasi di Desa Bontosunggu, Kecamatan Tamalatea, Kabupaten Jeneponto, Sulawesi Selatan. Prototipe pembangkit listrik tenaga ombak dengan menggunkan sebuah masukan air yang meruncing dengan tinggi tiang belakang $0.40 \mathrm{~m}$ dan tiang depan $0.20 \mathrm{~m}$ dengan lebar bagian belakang $0.20 \mathrm{~m}$ dan lebar bagian depan $0.30 \mathrm{~m}$. Prototipe ini juga memilki sebuah penampungan (reservoir) dengan tinggi $0.45 \mathrm{~m}$, lebar persegi empat 0.28 m. Dan pipa $1 / 2$ inci dengan panjang $1.8 \mathrm{~m}$ sebagai saluran air ke turbin air. Turbin air yang digunakan memilki 10 baling-baling untuk memutar sebuah generator (dinamo DC) 6 Volt 2.4 Watt. Variasi tinggi ombak yang digunakan adalah $0.32 \mathrm{~m}, 0.40 \mathrm{~m}$, dan $0.42 \mathrm{~m}$. Hasil penelitan menujukkan bahwa air mampu naik ke reservoir pada jam 11:00 sampai jam 14:00 dengan tinggi ombak bervariasi. Dan daya yang dapat dihasilkan oleh dinamo maksimal 0.7702 Volt dan minimal 1.1667 Volt. Prototipe pembangkit listrik tenaga ombak (PLTO) ini memiliki model tiga bangunan penting dan mampu menghasilkan energi listrik dengan tegangan rata-rata 1 volt.

Kata Kunci- Air, Ombak, Penampungan, Turbin Air, Dinamo.

\section{PENDAHULUAN}

Latar Belakang

Krisis energi diperkirakan akan melanda dunia sekarang dan yang akan datang. Hal ini dikarenakan semakin langkanya minyak bumi dan semakin meningkatnya permintaan energi disebabkan adanya pola pergeseran hidup manusia ke arah yang lebih berkembang.

Pembangkit terbarukan salah satu solusi untuk menangani krisis energi sekarang dan yang akan datang. Oleh karena itu kita harus berusaha memanfaatkan sumber daya yang ada di bumi ini sebagai energi terbarukan dengan sebaik-baiknya seperti energi angin, matahari, fosil dan air (ombak). 
Vertex Elektro, Vol 01, No. 02, Tahun 2019

sebagai energi terbarukan. Walaupun Pembangkit Listrik Tenaga Ombak (PLTO) kapasitas daya keluaranya tidak terlalu besar diantara energi terbarukan lainnya seperti Pembangkit listrik tenaga Air (PLTA) tetapi kami berharap pembangkit listik tenaga ombak ini dapat membantu masyarakat yang berada di pesisir pantai yang belum mendapatkan suplay listrik dari PLN. Dan dapat di terapkan serta di kembangkan kedepannya sebagai energi alternatif yang dapat menggantikan energi listrik konvensional. (Rubrik Teknologi · Majalah 1000guru $\cdot$ November 2013)

Berdasarkan latar belakang diatas, penulis tertarik untuk mengambil judul "Model Pembangkit Listrik Tenaga Ombak.

\section{Batasan Masalah}

Berdasarkan latar belakang di atas, maka penulis membatasi masalah dalam penelitian yaitu mendesain pembangkit tenaga ombak.

\section{Rumusan Masalah}

Yang menjadi rumusan masalah dalam tugas akhir ini adalah.

1) Bagaimana desain prototipe pembangkit listrik tenaga ombak?

2) Bagaimana pengujian dari prototipe pembangkit listrik tenaga ombak?

\section{Tujuan Penelitian}

Adapun tujuan yang ingin dicapai oleh penulis berdasarkan rumusan masalah ombak diatas adalah :

1) Diperoleh desain pembangkit listrik tenaga ombak (PLTO).

2) Diperoleh hasil dari pembangkit listrik tenaga ombak (PLTO).

\section{Manfaat Penelitian}

Berdasarkan perancangan pembangkit listik tenaga gelombang laut tersebut diatas, maka manfaat yang diharapkan dari hasil penelitian ini adalah:

1) Sebagai sarana penunjang belajar dan pembelajaran.

2) Menambah ilmu pengetahuan yang terkait dengan PLTO (Pembangkit Listrik Tenaga Ombak).

3) Berguna bagi yang berminat untuk penelitian lebih lanjut.

\section{TINJAUAN PUSTAKA}

Energi Terbarukan

Energi terbarukan adalah sumber energi yang cepat dipulihkan kembali secara alami, dan prosesnya berkelanjutan. Energi terbarukan dihasilkan dari sumber daya energi yang secara alami tidak akan habis bahkan berkelanjutan jika dikelola dengan baik. Energi terbarukan kerap disebut juga sebagai energi berkelanjutan. (Turcotte, D. L.; Schubert, G. .2002)'

Mengatasi Pemanasan Global

Energi terbarukan sering dianggap sebagai cara terbaik untuk mengatasi pemanasan global dan perubahan iklim. Energi terbarukan akan mengurangi penggunakan bahan bakar fosil yang terus kita bakar, mengurangi pembakaran bahan bakar fosil berarti juga mengurangi emisi karbon dioksida dan memberikan dampak perubahan iklim yang lebih rendah. (Keddy P. A. 2010).

\section{Pengertian Ombak}


Vertex Elektro, Vol 01, No. 02, Tahun 2019

Gelombang laut (Ombak) adalah pergerakan naik dan turunnya air dengan arah tegak lurus permukaan air laut yang membentuk kurva/grafik sinusoidal. Gelombang laut biasanya disebabkan oleh angin. (Djabbar, M., A., 2007).

Gelombang Laut selalu menimbulkan sebuah ayunan air yang bergerak tanpa henti-hentinya pada permukaan air laut dan jarang dalam sama sekali diam. Secara teori, pengertian gelombang laut (ideal) adalah pergerakan naik turunnya muka air laut yang membentuk lembah dan bukit mengikuti gerak sinusoidal.

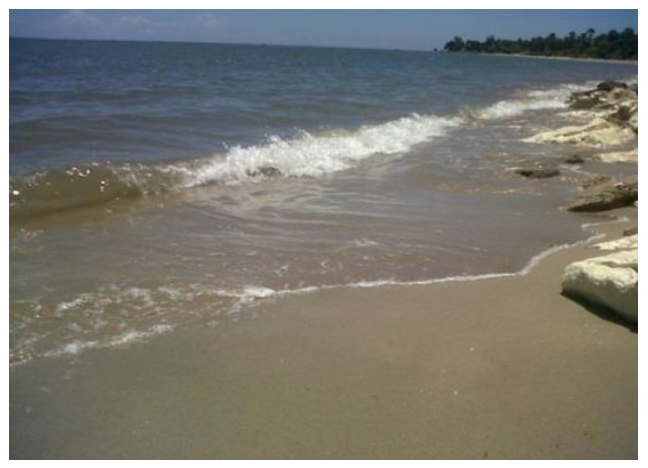

Gambar 1. Ombak

\section{Pengertian Pembangkit Listrik Tenaga Ombak}

Pembangkit listrik tenaga ombak adalah suatu pembangkitan energi listrik yang merubah energi mekanik gelombang ombak menjadi energi listrik.

\section{Turbin}

Dalam pembangkit listrik tenaga air (PLTA) turbin air merupakan peralatan utama selain generator. Turbin air adalah alat untuk mengubah energi potensial air menjadi energi mekanik. Energi mekanik ini kemudian diubah menjadi energi listrik oleh generator.. (W. A. Doble, The Tangential Water Wheel, 1899 ).

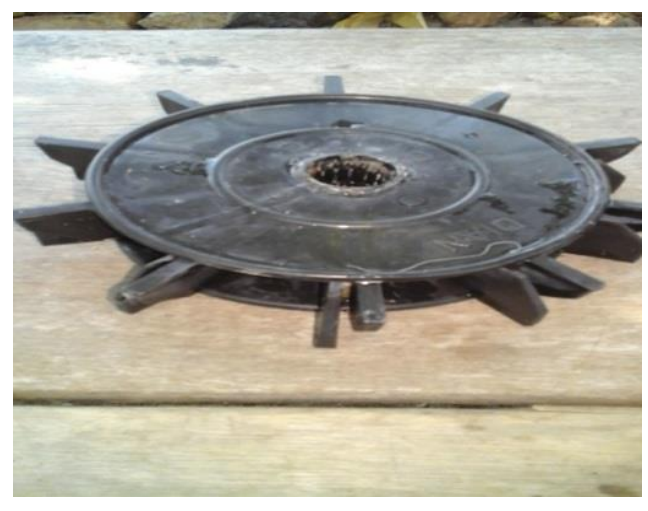

Gambar 2. Turbin air

\section{Fungsi Turbin}

Turbin berfungsi untuk mengubah energi potensial menjadi energi mekanik. gaya jatuh air yang mendorong baling-baling menyebabkan turbin berputar. Turbin air kebanyakan seperti kincir angin, dengan menggantikan fungsi dorong angin untuk memutar baling-baling digantikan air untuk memutar turbin. (W. F. Durrand, 1939)

\section{Prinsip Kerja Turbin}

Turbin air mengubah energi potensial air menjadi energi mekanis. Energi mekanis diubah dengan generator listrik menjadi tenaga listrik. Berdasarkan prinsip kerja turbin dalam mengubah energi potensial air menjadi energi mekanis. (W. F. Durrand, 1939) 
Vertex Elektro, Vol 01, No. 02, Tahun 2019

\section{Generator}

Generator adalah sebuah equipment listrik yang mengadopsi prinsip percobaan seorang ilmuwan bernama faraday. Hasil percobaannya yaitu memutar magnet dalam kumparan atau sebaliknya, ketika magnet digerakkan dalam kumparan maka terjadi perubahan fluks gaya magnet (perubahan arah penyebaran medan magnet) di dalam kumparan dan menembus tegak lurus terhadap kumparan sehingga menyebabkan beda potensial antara ujung-ujung kumparan (yang menimbulkan listrik). [ Michael Faraday 1831-1832 ].

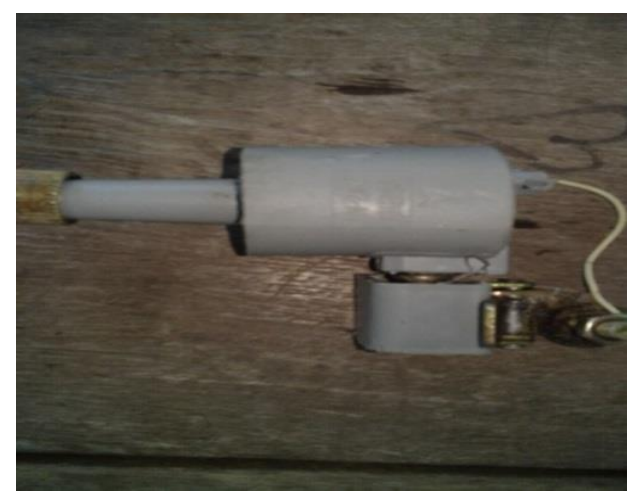

Gambar 3. Generator DC

(Dinamo $6 \mathrm{~V}$ )

\section{Prinsip Kerja Generator}

Prinsip kerja generator sangatlah sederhana yaitu kumparan jangkar yang memotong medan pada magnet yang dihasilkan kumparan medan akan menimbulkan gerak gaya listrik (GGL) terhadap kumparan jangkar. Cara kerja generator yang utama adalah adanya medan magnet dan pemotong medan magnet.

\section{METODE PENELITIAN}

\section{Lokasi dan Waktu Penelitian}

Penelitian dilakukan dilaksanakan selama bulan November 2015 berlokasi di Desa Bontosunggu, Kecematan Tamalatea, Kabupaten Jeneponto, Sulawesi Selatan.

\section{Jenis Penelitian}

Metode yang dipakai adalah penelitian lapangan yang didasarkan pada data pengamatan dan pengukuran dilapangan pada daerah pesisir pantai yang menjadi lokasi penelitian.

\section{Peralatan}

Beberapa peralatan yang digunakan dalam penelitian ini adalah Obeng, Meteran,Tank, Gergaji.

\section{Bahan}

Beberapa bahan yang digunakan dalam penelitian yaitu, generator, kabel, turbin air, lampu led, dan pipa.

\section{Skema Penelian}

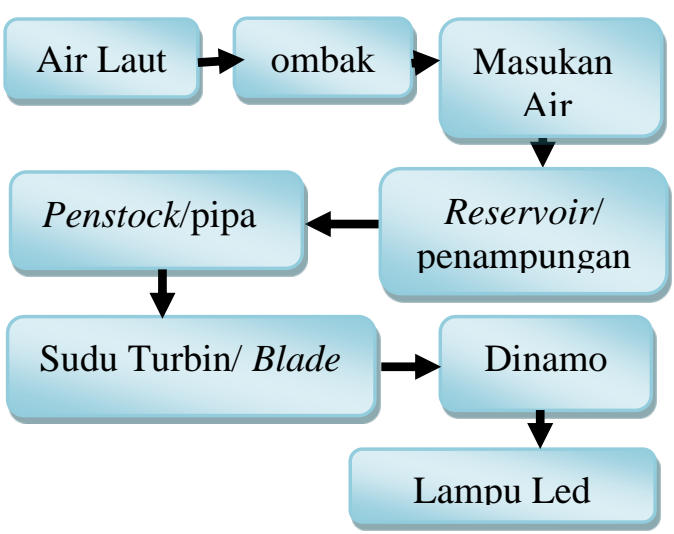

Gambar 4. Skema penelitian 
Vertex Elektro, Vol 01, No. 02, Tahun 2019

Energi alam (ombak) menghantam penstock/pipa kemudian air mengalir ke penampungan (reservoir).Setelah air terkumpul kemudian diterjunkan keturbin agar generator dapat berputar untuk menghasilkan energi listrik.

\section{Jadwal penelitian}

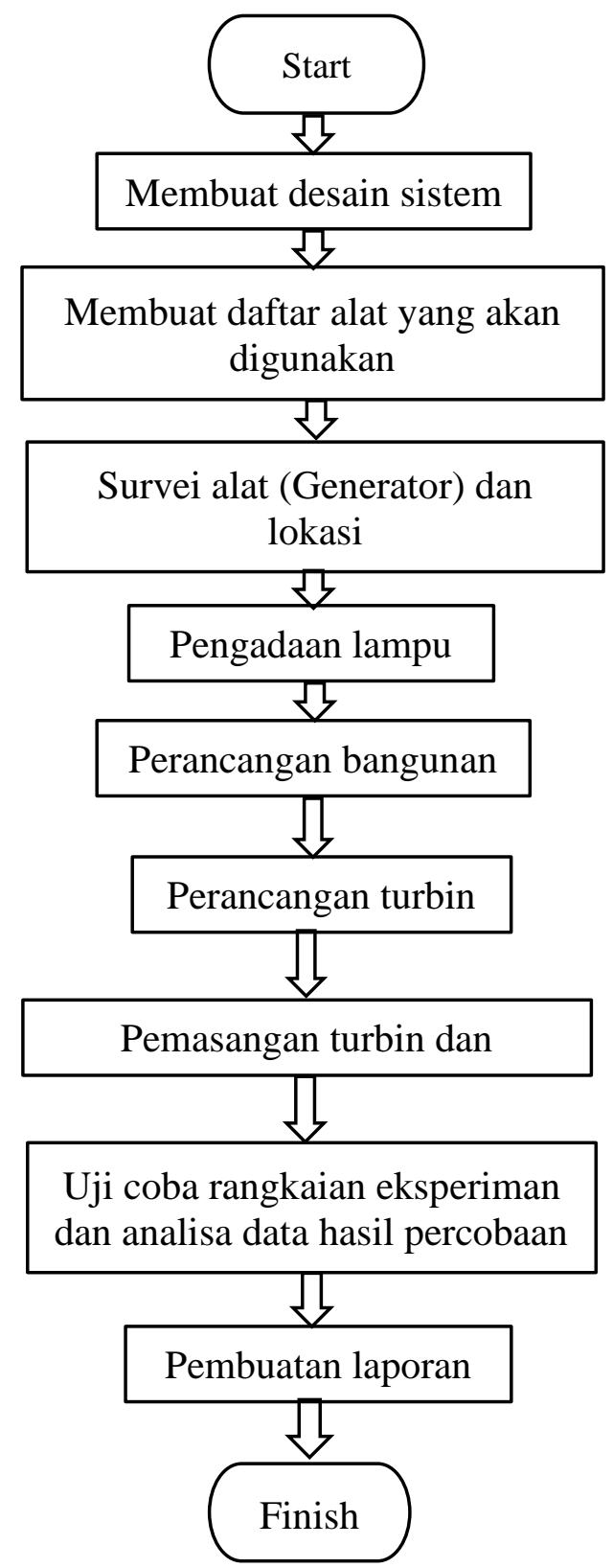

Gambar 5. Jadwal penelitian

\section{Hasil survei lapangan}

Percobaan dilakukan pada tanggal 10-17 Mei 2016. Penelitian melakukan observasi dan survei lapangan dan Pengujian alat rancang yang dilakukan di Desa Bontosunggu, Kecematan Tamalatea, Kabupaten Jeneponto.

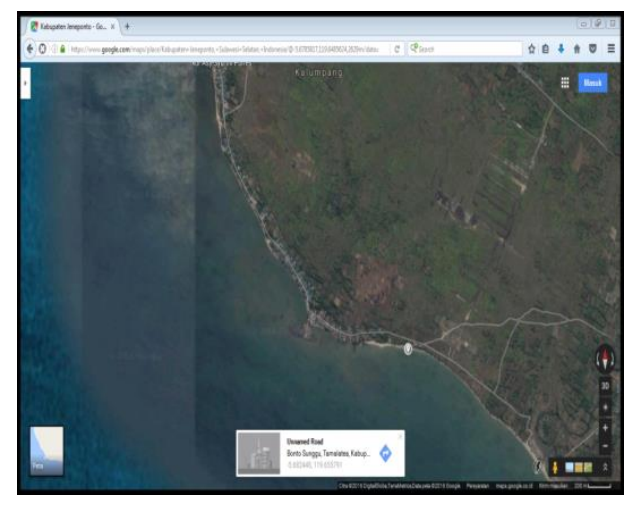

Gambar 6. Google maps lokasi penelitian.

\section{Hasil perancangan}

Hasil perancangan yang diperoleh merupakan hasil pengetesan pembuatan pembangkit listrik tenaga ombak yang merubah energi mekanik gelombang ombak menjadi energi listrik dalam skala kecil.

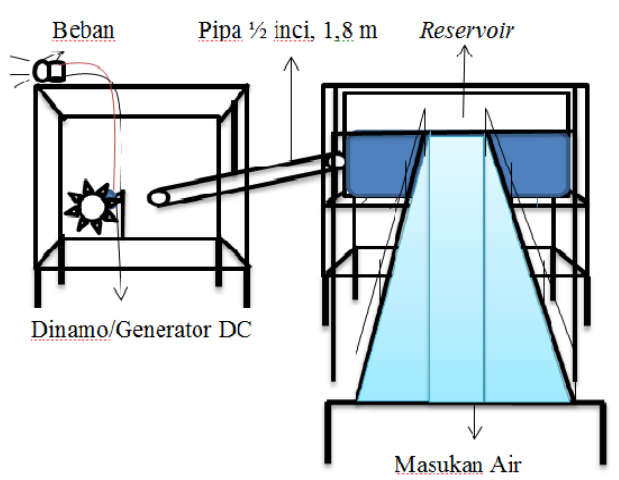

Gambar 7. Hasil perancangan.

\section{Hasil pengukuran ombak}

\section{HASIL DAN PEMBAHASAN}


Data ketinggian ombak di desa bontosunggu.

\section{Data Hasil Pengukuran Tinggi Ombak Di Pantai}

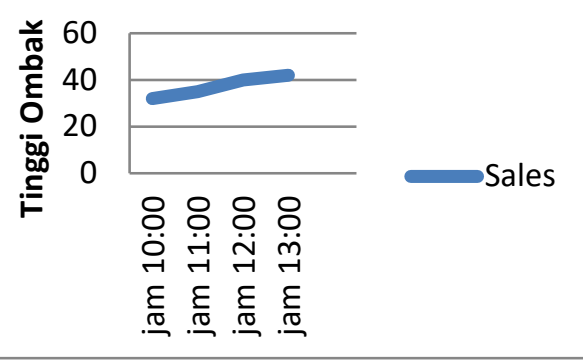

Gambar 8. Data hasil pengukuran Ombak.

Pada pukul 10:00 sampai dengang pukul 13:00 Rata-rata ketinggian ombak maksimal $0,30 \mathrm{~m}$ dan rata-rata ketinggian ombak minimal 0,42 m.

\section{Hasil pengukuran volume debit air}

Debit air adalah banyaknya volume zat cair yang mengalir pada tiap satu satuan waktu, biasanya dinyatakan dalam satuan liter/detik atau dalam satuan meter kubik $\left(\mathrm{m}^{3}\right)$ per detik.

Tabel 1. Pengukuran debit air masuk kepenampungan (reservoir)

\begin{tabular}{|c|c|c|c|}
\hline No & $\begin{array}{c}\text { Hemp } \\
\text { asan }\end{array}$ & $\begin{array}{c}\text { Volume } \\
\text { air }\left(\mathrm{m}^{3}\right)\end{array}$ & $\begin{array}{c}\text { Waktu } \\
\text { hempasan } \\
\text { berikutnya } \\
\text { (detik) }\end{array}$ \\
\hline 1 & 1 & 0.002 & 2.5 \\
\hline 2 & 2 & 0.0015 & 1 \\
\hline 3 & 3 & 0.0025 & 2 \\
\hline 4 & 4 & 0.003 & 3.5 \\
\hline 5 & 5 & 0.002 & 3 \\
\hline
\end{tabular}

Tabel 2. Pengukuran debit air keluar

\begin{tabular}{|c|c|c|c|}
\hline No & $\begin{array}{c}\text { Volume } \\
\left.\text { air(m }{ }^{3}\right)\end{array}$ & $\begin{array}{c}\text { Waktu } \\
(\text { detik) }\end{array}$ & $\begin{array}{c}\text { Tinggi } \\
\text { terjun } \\
\text { air }(\mathrm{m})\end{array}$ \\
\hline 1 & 0.003 & 6 & 0.20 \\
\hline 2 & 0.005 & 10 & 0.20 \\
\hline 3 & 0.008 & 22 & 0.20 \\
\hline
\end{tabular}

Pengukuran debit air yang keluar ke turbin minimal sebanyak 3 liter dalam waktu 6 detik dan maksimal 8 liter dalam waktu 22 detik.

Hasil pengukuran Tehadap tegangan output dan arus out yang dihasilkan (generator).

Percobaan dilakukan pada tanggal 10-17 Mei 2016. Setelah melakukan uji coba terhadap turbin air, hasilnya bahwa turbin air baru bisa berputar dan menghasilkan listrik pada ketinggian ombak 0,32 m sampai 0,42 m.

Pada pengujian seluruh komponen turbin air yang pertama dilakukan adalah mengetahui ketinggian ombak pada tempat yang akan diujikan. Diikuti dengan proses merancang turbin air dan mempersiapkan alat dan bahan yang akan digunakan. Pengujian alat rancang dilakukan di Desa Bontosunggu, Kecematan Tamalatea, Kabupaten Jeneponto.

Dari hasil penelitian yang penulis lakukan, pada pagi hari atau tepatnya antara pukul 06:00 sampai dengan 09:00 pagi data ketinggian ombak berkisar 0.09-0.10 m tidak terlalu tinggi dengan tegangan 0 volt. Kondisi tersebut hampir 
Vertex Elektro, Vol 01, No. 02, Tahun 2019

sama dengan penelitian pada sore hari tepatnya pukul 14:00 sampai dengan pukul 24:00 malam data ketinggian ombak tidak begitu tinggihanya

Tablel 3. Data hasil pengukuran tegangan output dan arus out yang dihasilkan dinamo dari jam 10:00 sampai jam 11:00.

\begin{tabular}{|c|c|c|c|}
\hline $\begin{array}{c}\mathrm{N} \\
\mathrm{o}\end{array}$ & $\begin{array}{c}\text { Tegangan } \\
\text { (volt) }\end{array}$ & $\begin{array}{c}\text { Arus } \\
\text { (Ampere) }\end{array}$ & $\begin{array}{c}\text { Daya } \\
\text { (Watt) }\end{array}$ \\
\hline 1 & 1.0129 & $3.6 \mathrm{~mA}$ & $\begin{array}{c}3.6464 \\
4\end{array}$ \\
\hline 2 & 0.7702 & $2.3 \mathrm{~mA}$ & $\begin{array}{c}1.7714 \\
6\end{array}$ \\
\hline 3 & 0.9527 & $3.1 \mathrm{~mA}$ & $\begin{array}{c}2.9533 \\
7\end{array}$ \\
\hline
\end{tabular}

Dari tabel diatas menampilkan luaran generator dalam pengukuran yang dilakukan dari pukul 10:00-11:00 siang. Ada dua jenis luaran terukur yakni tegangan terminal dan arus yang keluar dari generator. Tegangan terendah yang mampu dihasilkan minimal 0,7702 Volt dan tertinggi adalah maksimal 1,1029 Volt. Dengan demikian, tegangan luaran generator berkisar 0,78 terhadap 6 volt Dan arus yang dihasilkan minimal 2,3 $\mathrm{mA}$ dan arus maksimalnya adalah 3,6 $\mathrm{mA}$.

Tabel 4. Data hasil pengukuran tegangan output dan arus out yang dihasilkan dinamo dari jam 11:00 sampai jam 12:00.

\begin{tabular}{|c|c|c|c|}
\hline $\mathrm{N}$ & $\begin{array}{c}\text { Tegangan } \\
\mathrm{o}\end{array}$ & $\begin{array}{c}\text { Arus } \\
\text { (volt) }\end{array}$ & $\begin{array}{c}\text { Daya } \\
\text { (Ampere) }\end{array}$ \\
(Watt) \\
\hline
\end{tabular}

\begin{tabular}{|c|c|c|c|}
\hline 1 & 1.0129 & $3.6 \mathrm{~mA}$ & $\begin{array}{c}3.6464 \\
4\end{array}$ \\
\hline 2 & 1.1667 & $3.7 \mathrm{~mA}$ & $\begin{array}{c}4.3167 \\
9\end{array}$ \\
\hline 3 & 0.8398 & $2.8 \mathrm{~mA}$ & $\begin{array}{c}2.3514 \\
4\end{array}$ \\
\hline
\end{tabular}

Dari tabel diatas menampilkan luaran generator dalam pengukuran yang dilakukan dari pukul 11:00-12:00 siang. Ada dua jenis luaran terukur yakni tegangan terminal dan arus yang keluar dari generator. Tegangan terendah yang mampu dihasilkan minimal 0,8398 Volt dan tertinggi maksimal 1,1667 Volt. Dan arus yang dihasilkan minimal 2,8 $\mathrm{mA}$ dan arus maksimalnya adalah 3,7 $\mathrm{mA}$.

Tabel 5. Data hasil pengukuran tegangan output dan arus out yang dihasilkan dinamo dari jam 12:00 sampai jam 13:00.

\begin{tabular}{|c|c|c|c|}
\hline $\begin{array}{c}\mathrm{N} \\
\mathrm{o}\end{array}$ & $\begin{array}{c}\text { Tegangan } \\
\text { (volt) }\end{array}$ & $\begin{array}{c}\text { Arus } \\
\text { (Ampere) }\end{array}$ & $\begin{array}{c}\text { Daya } \\
\text { (Watt) }\end{array}$ \\
\hline 1 & 1.0129 & $3.6 \mathrm{~mA}$ & $\begin{array}{c}3.6464 \\
4\end{array}$ \\
\hline 2 & 0.7702 & $2.3 \mathrm{~mA}$ & $\begin{array}{c}1.7714 \\
6\end{array}$ \\
\hline 3 & 1.1578 & $3.7 \mathrm{~mA}$ & $\begin{array}{c}4.2838 \\
6\end{array}$ \\
\hline
\end{tabular}

Dari tabel diatas menampilkan luaran generator dalam pengukuran yang dilakukan dari pukul 12:00-13:00 siang. Ada dua jenis luaran terukur yakni tegangan terminal dan arus yang keluar dari generator. Tegangan terendah yang mampu dihasilkan minimal 0,7702 Volt dan tertiggi maksimal 1,1578 Volt. Dan 
Vertex Elektro, Vol 01, No. 02, Tahun 2019

arus yang dihasilkan minimal 2,3 mA dan arus maksimalnya adalah 3,7 mA.

\section{PENUTUP}

\section{Kesimpulan}

Dari hasil penelitian dapat disimpulkan bahwa prototipe pembangkit listrik tenaga ombak (PLTO) ini memiliki model tiga bangunan penting yaitu masukan air yang berbentuk runcing, bangunan penampugan (reservoir) dan bangunan rumah turbin. Prototipe ini mampu menghasilkan energi listrik dengan tegangan rata-rata 1 volt.

\section{Saran}

Saran yang dapat kami berikan pada pembahasan ini adalah agar kita bisa dapat memanfaatkan ombak menjadi sumber energi alternatif untuk pembangkit listrik yang akan datang.

\section{DAFTAR PUSTAKA}

Dahuri,H.Rokhmin,dkk.1996.Pengelolaa n Sumber Daya Wilayah Pesisir dan Lautan, cetakan 1.Pradnya Paramita.Jakarta.

http://www.alpensteel.com/article/51113-energi-lain-lain/161pembangkit- listrik-tenagaombak-dikembangkan.html.

http://energi.infogue.com/pemanfaatan energi_ombak_sebagai_pembangk it_tenaga_listrik Iftitah Nafika Penulis adalah mahasiswa jurusan biologi FMIPA Universitas Negeri Malang (UM)March 20, 2008 at 10:37 am.

Yuli Setyo Indartono, Graduate School of Science and Technology, Kobe University, Japan Resnick,
Halliday.2004.Fundamentals.of.P hysics.Willey United Nations Convention on The Law of The Sea ["Convention"].10 Desember 1982. New York

http://www.pengertianahli.com/2014/04/ pengertian-generator-apa-itu generator.html

W. A. Doble, The Tangential Water Wheel, Transactions of The Amarican Institute of Mining Enginerings, Vol. XXIX, 1899.

W. F. Durrand, The pelton Water Wheel, Stanford University, Mechanical Engineering, 1939.

Turcotte, D. L.; Schubert, G. .2002, Geodynamics (2 ed.), Cambridge, England, UK: Cambridge University Press.

Demirbas, A. . (2009). "Political, economic and environmental impacts of biofuels: A review". Applied Energy 86: S108-S117

Boyle, G. (ed), Renewable Energy: power untuk masa depan yang berkelanjutan. Open University, Inggris, 1996

Karyanto, E (2000). Panduan Reparasi mesin Diesel. Penerbit Pedoman Ilmu Jaya Jakarta.

http://www.alpensteel.com/article/52106-energi-laut ombak gelombang/2490--pemampaantanenergi-listrikgelombang-laut.html.

M. M Dandekar dan K. N Sharma Penerjemah, D. Bambang Setyadi, sutanto. Pembangkit Listrik Tenaga Air,1991.Cet 1.-,Jakarta: Penerbit Universitas Indonesia (UI-Press).

Kadir, Abdul, 1995. Energi Sumber daya. Inovasi tenaga listrik, 
Vertex Elektro, Vol 01, No. 02, Tahun 2019

potensi ekonomi Cet 1. Edisi

Kedua/Revisi-Jakarta: Penerbit

Universitas Indonesia (UI-Press) 